\title{
STUDIES ON THE GEOMORPHIC PROCESSES OF OVERLAND FLOW AND MASS MOVEMENTS IN THE BRAZILIAN GEOMORPHOLOGY
}

\section{OLGA CRUZ*}

\begin{abstract}
There have been sharp changes in Brazilian geomorphological studies, from the fifties to the seventies of the twentieth century, due to new theoretical developments that have been opposed to the Davisian paradigm. Such studies of deposits correlative to erosional episodes in the Cenozoic stimulated investigation and interpretation with new techniques of weathered, pedogenetic and colluvial materials. They led to constitution of researcher teams under the leadership, among others, of Ab'Saber, Bigarella and Tricart. At the time, other research was already under way on the estimation of losses by erosion in Brazilian agricultural soils.

Geomorphologic research on a broader scale was much influenced, during the seventies, by several external factors, such as techniques of remote sensing, new publications stressing the role of tropical and subtropical process studies, relating forms, materials and processes, catastrophic landslides in São Paulo and Rio de Janeiro, in the 1966/67 summer, new knowledge of quantification, geochemistry, soil mechanics, meteorology and climatology of atmospheric circulation on the South Atlantic, forest clearing, draughts and fight against soil erosion.

The visits of professor Yan De Ploey from the Catholic University of Leuven, Belgium, in 1977/78/79, fostered much Brazilian research on the dynamics of natural geomorphic processes happening on hillslopes, plains and coasts of tropical humid areas, such as overland and channel flow, and mass movements. De Ploey influenced and brought about remarkable changes in several geomorphological trends, always linked to field experimentation, such as the application of troughs to collect pluvial waters on slopes, or studies on the movement of the thick weathered materials and colluvia using sheargraph, or still detection of gullied risk areas and measurements of fluvial waters velocity and transportation power.

In the eighties and nineties, attention to erosional phenomena indicated that natural processes are becoming faster, influenced by anthropic dynamics which interferes with nature. The consolidation of the Brazilian Geomorphology Union confirms the wish for more participation of geomorphologists in the study of contemporary serious environmental problems.
\end{abstract}

The development of new paradigms in geomorphology and the application of new techniques in the decades between the fifties and the seventies of the XX century, necessitated deep changes in Brazilian geomorphological studies. One slowly passes from a geomorphology of observational research, in regional to continental scale, on Cenozoic erosional levels and surfaces, into more detailed scales, focusing on the study of hillslopes and their correlative deposits.

Methodological orientation from foreign geographers and, specifically, the visits of scientists during the International Geographical Congress in Rio de Janeiro in 1956 decidedly influenced Brazilian Geomorphology. Texts were published, mostly French, on the evolution of the relief, as well as on the effects of climate and vegetation in the diverse morphoclimatic and structural regions of the world. According to Ab'Saber (1958), there was a "true internal revolution in modern Brazilian geomorphology".

Starting in the sixties, there was a strengthening of the studies of correlative deposits related to topographic and planation levels of the Cenozoic erosional phases. Sedimentological research stimulated investigation of depositional features in soil profiles, affording firm bases for the interpretation of weathering, pedogenetic and colluvial materials in erosional levels and on hillslopes. It was a phase of intensive team research under the leadership of, among others, A.N. Ab'Saber, J.J. Bigarella, R. Mousinho and J.X. Silva, G.O. Andrade, G.V. Barbosa, T.C. Silva, A. Christofoletti and A.A.N. Moreira, working on mapping and, specially, on the Quaternary of the country.

At this time, Ab'Saber founded the bulletin Noticia Geomorfologica, in São Paulo, later taken over by A. Christofoletti in Campinas. With his extraordinary gift for synthesis and full knowledge of the diverse Brazilian landscapes, Ab'Saber organized geomorphologic and biogeographic maps, present and Quaternary, of the great morphoclimatic domains and phytogeographic provinces of Brazil (Ab'Saber 1966, 1970, 1973). He published his maps in a deeply original and ingenious presentation of Brazilian tropical and subtropical landscapes. Meanwhile he proceeded to research the Quaternary, and established three main levels of geomorphological research: i) compartmentation of relief units according to form and topography; ii) superficial structure and respective materials; iii) physiology and dynamics of present processes (Ab'Saber 1969). Within this methodological orientation, Ab'Saber called attention to the action of geomorphic processes on hillslopes. Ab'Saber already had national stature as a geographer-geomorphologist, as a teacher, researcher and human being; he took his place as a confirmed leader of Brazilian Geomorphology.

Joao Jose Bigarella pointed towards new research lines on correlative deposits of hilltops and slopes, in diverse Brazilian levels and surfaces molded during the Cenozoic. His texts, illustrated with detailed and enlightening sequential-stratigraphic profiles, afforded regional, local and punctual instances. In 1965, Mousinho and
Bigarella, writing on processes of mass movements in the transportation of debris from rock weathering referred to rainwash action, creep, solifluxion, sliding of coluvia and on their importance to the evolution of hillslopes. Bigarella et al. (1970) worked again on sliding, this time on marine sands at Guaratuba, Parana. With his group, Bigarella organized the International Symposium on the Quaternary held in South Brazil in 1975.

Tricart (1961) and Tricart \& Cailleux (1965), in papers and conferences on relief forms in tropical humid countries, refer to weathering and pedogenesis, to rainwash and river flow and to mass movements. They assert that a hillslope should not be defined only through its surface and declivity, but also through dynamical aspects of erosion, transport and accumulation in space and time. Such new approaches were particularly well presented by Tricart (1977).

Experiments on soil erosion had been in progress in the U.S.A. since the twenties; also Wischmeier (1959) had made use of the Universal Soil Loss Equation by standard plots. In Brazil, Bertoni (1978), Lombardi and Bertoni (1975) and Lombardi et al. (1979) were pioneers, working with field plot experiments at the Instituto Agronomico de Campinas. As early as 1940, De Martonne called attention to mass movements of alteration materials on southeastern Brazilian hillslopes. In 1949, Stenberg referred, at the National Geography Council in Rio de Janeiro, to floods and mass movements in the Paraiba valley. Ruellan (1953) stressed the action of overland flow during rainstorms (enxurradas) on the Brazilian relief, calling attention to the strength and impact of tropical rains. Queiroz Neto \& Christofoletti (1963) also referred to the importance of rainwash on slopes in the interior of São Paulo, and Rochefort (1958) related rainfall to river flow in tropical and subtropical Brazil.

Other Brazilian and foreign authors continued to stress the role of tropical and subtropical areas to studies of processes, with the help of photo-interpretation techniques. In the 1966-1967 summer, continuous rains, in long and intense episodes on the scarps of the Serra do Mar, in the states of Rio de Janeiro and São Paulo, triggered catastrophic planar landslides and avalanches, with floods, destruction of hydroelectric plants and highways. The need became evident for the study of processes (Meis \& Silva 1968, Cruz 1974, 1975, Guidicini et al. 1976, Coelho Neto 1979, Bigarella \& Suguio 1979).

New analytical studies on hillslopes stressed the relationships between forms, materials and processes. New ideas along the lines of the geosystems paradigm, of quantification data (Christofoletti 1971) and photointerpretation, both of radar (Projeto RADAM) and satellite images (INPE), went together with new meteorological and climatological informations on atmospheric dynamics and South Atlantic cold fronts, later complemented by data on El Niño and La Niña and their pluviometric and hydrologic consequences. New laboratories of geomorphology, pedology, remote sensing and sedimentology were opened consequent to the acquisition of 
geochemical and soil mechanics information. Additionally, destruction of biodiversity, deforestation, dry periods and fight against erosion have led, in the seventies and eighties, to enhanced interest in research on a broader scale and on the study of the mechanisms of hillslope processes.

Brazil extends from the equatorial to the subtropical belt. The largest part of its eastern facade is characterized by the mar de morros (sea of hills) domain ( $\mathrm{Ab}^{1}$ Saber 1966), covered with Atlantic Forest, with convex upslopes and rectilinear lower slopes, sometimes with benches or shoulders, sometimes concave by the colluvial accumulation, forming rampas or debris cones. In the Southeast and partly in the South, the hills are preceded by the scarps of the Serra do Mar, which limits the Atlantic plateau. Three main groups of natural processes take place on the slopes of these humid tropical areas: (i) weathering-pedogenesis, forming thick weathered mantles reworked by (ii) overland and sub-surface flow, and river flow, and by (iii) mass movements, especially on scarped slopes, such as those of Serra do Mar and Serra da Mantiqueira, in the Southeast, and the Serra Geral, in the South. Such natural processes vary according to geographic position, declivity, range and length of the scarps, as well as their geological nature, the thickness of alteration beds and climatic conditions. An increasing and relentless anthropogenic influence has speeded up such dynamics, especially in intensively inhabited areas of risk, at times resulting in catastrophic debris and mudflows.

I.G.U. Commissions in 1976 and 1980, on geomorphological processes and experimental geomorphology, measurements, theory and application in geomorphology, international publications, especially those aiming at processes, as well as Brazilian publications on gullying, runoff and human action have stimulated Brazilian studies on processes. The visits of Professor Yan De Ploey from the Catholic University of Leuven-Belgium encouraged and oriented research on process dynamics, especially fieldwork. De Ploey had been in Brazil in 1975 for the first time, to take part in the International Symposium on the Quaternary. In 1977 he came to the Department of Geography, University of São Paulo, to give an intensive course, to give talks and to participate in fieldwork with postgraduate students. His presence then and again in 1978 and 1979 had an enormous importance by influencing, helping and even changing methods in the sense of stressing field experimentation. Such are the analyses of mass movements in the Serra do Mar scarps (De Ploey \& Cruz 1979, De Ploey 1988) and Campos do Jordão Plateau (De Ploey et al. 1983), as well as gullying at the limits of the São Paulo sedimentary basin (Cruz $\&$ Modenesi 1978). New field techniques were then tried, including the application of sheargraph and rain simulator and measurements of depositional materials from landslides (Cruz et al. 1980).

Especially important were the results of a research on the relationship between quantity and intensity of rainfall and the sheetwash with the materials transported, collected, for three years, in Gerlach troughs on scarps under Atlantic Forest, or planted with Pinus, on slide scars (Cruz 1982). Some of the conclusions refer to the importance of herbaceous vegetation and litter layer on the reduction of erosion by sheetwash under forest. Not less important is the fact that troughs on slide scar slopes in reforested area collected a greater load of solid materials than troughs under forest, i.e., there was more erosion on the reforested area.

Postgraduate students followed De Ploey's line producing master dissertations and doctorate theses, such as Baccaro (1983 and 1990), on processes of mass movements on the Serra do Mar scarps and on overland flow in sandstone areas under cerrado in the Brazilian Midwest; Pianaro (1982), on the hydrodynamics of one of the basins of Serra do Mar, in Parana; Domingues (1983) on river flow and hillslope evolution in one of the river basins of the Serra do Mar, in São Paulo; Carvalho (1984) studies the sheetwash with troughs on coastal slopes in São Paulo; Mauro (1990) analyzes gullying in sandstones and basalts on the São Paulo western plateau; Jordão (1991) studies the relationships between mining and hillslope evolution; Furian (1988) studies sheetwash in experimental plots on the Atlantic Plateau and presents a thesis at Caen, France, on the present dynamics of slides, starting from the relationships between morphogenesis and pedogenesis in the evolution of the Serra do Mar slopes; Colangelo (1990) studies mass movements on the lakeside slopes of the Paraibuna dam, in the Atlantic Plateau. He joins the analysis of balance limit to the model of infinite slope, aiming at an evaluation of mass movements based in data on previous landslides.
At the same time, De Ploey visited the Departament of Geosciences at de Federal University of Rio de Janeiro, lecturing and participating in fieldworks organized by Mousinho de Meis. There was an important meeting at Bananal, on gullying and the application of tensiometers and collecting troughs in the study of overland flow in exhausted soils of old coffee plantations on the Precambrian Atlantic Plateau. Under De Ploey's supervision, Coelho Neto (1985) presented a doctor's thesis on soil erosion and hillslope hydrology, in Leuven, Belgium. Guerra (1994) studied soil erosion processes in simulated rainfall experiments and Cunha (1993), fluvial dynamics and drainage basins.

It is important to stress the role of the Brazilian Association of Engineering Geology, which promoted a first symposium at Curitiba in 1980 and a second in 1981 on the control of erosion. Besides discussions of problems of urban and rural erosion, the symposia included contributions on the erosional processes linked to highway systems, concluding that human intervention is the major responsible for the worsening of the erosion processes, due to a total lack of ecological awareness, of the communities, of technicians and of the public administration. One of the data is that agriculture loses, yearly, in the State of São Paulo, 194 million tons of fertile soil. In the 1984 (Belo Horizonte) and 1987 (São Paulo) symposia, special attention was given to erosional processes in Serra do Mar and Serra Geral slopes, to gullying (voçorocas), to erosion of reservoir margins, and on their hydrogeologic impact. In 1993, besides these items, other work focused on the increased sediment yield consequent to flooding in urban areas, on the environmental impact of refuse, as well as in cartography, and managing of risk areas. In 1996 and 1999, were discussed diagnoses and proposals for the evaluation and treatment of risk areas, on landfill with solid refuse and on contamination of subsuperficial and subterranean water, on alteration and laterization of soils and on problems stemming from mining activities.

Several works, especially from government agencies, have been presented with agronomical emphasis, trying to relate erosion to rainfall, and specifically to its intensity. Other experimental work has been done on closed plots under diverse plant cover and uses of slope soils. Such experiments perform statistical analysis of superficial materials, or measurements of creep, or of rain erosivity, sometimes applying the Bertoni (1978) equation, based in Wischmeier. Such are the theses by Casseti (1984) on the Goiania plateau, Pacheco (1991) on the scarps of the Serra Geral in Rio Grande do Sul, Suertegaray (1987) in the sand wastes of Quaraí, Rio Gande do Sul, or still Tavares (1986) in the western plateau of São Paulo. Otherwise, Colangelo (1995) related indexes of rain frequency and magnitude with the hydraulic conductivity of weathered and colluvial materials from slumps on the Atlantic Plateau, and their resistance to shearing, as measured by the sheargraph.

In 1982, Ab'Saber identified critical areas of degradation; he called attention in 1985 to breaks of ecological balance in the Serra do Mar at Paranapiacaba, São Paulo, polluted for at least 20 years by factories in Baixada Santista. Government agencies started strategies of recuperation, with transplantation of native trees and seedlings from the air in areas hard to reach (Pompeia et al. 1989). However many irregular dwellings were built, invading other areas identified as of risk. Every summer, in general very rainy, serious slide problems afflict a poor population that ends up by inhabiting shanties or small brick houses in forbidden areas. This leads to impermeability and weakening of the slopes, robbing them from their natural defenses and causing landslides. It is important to note that such areas of risk are in general characterized by elongate steep slopes and broad topographical ranges, or, on the plains, connected to meander belts. During very wet summers, with long and intense rainy episodes soils and thick bedrock weathered materials, with many blocks, tend to move, even under forest or in areas of reforestation. They are of course areas of risk and of permanent protection.

The accentuation of current erosional processes to be seen on several sectors of the Brazilian coast, especially in the last two decades, has promoted studies on wave and tidal currents and on the influence of climatic processes on the beach and foreshore. Tide measurements by oceanographic institutions, application of geoprocessing techniques and experimental research on littoral and coastal areas were made in São Paulo by Modenesi (1969), Furtado (1978), Batres (1978), Modenesi et. al. (1983), Poncano (1985), Tessler and Furtado (1983), Souza (1997); in Rio Grande do Sul, by Villwock (1987), Bernardi et al. (1987), Tomazelli \& Vilwock (1989); in Rio de Janeiro, by Muehe 
(1984), Muehe et al. (1989); in Bahia, by Farias et al (1985), Bittencourt et al (1990); in Maranhao, by Feitosa (1996); in Santa Catarina, by Duarte (1981, 1995), Abreu Castilhos \& Correa (1991), Horn Filho et al (1994), Ore et. al. (1994), Pellerin \& Paulino (1996), Diehl (1997), Cruz (1998), Herrmann (1999); in Paraná, by Bigarella (1978), Angulo (1989), Kohler (1996), Canali et al. (1999), among many Brazilian researchers, in seashore coastal areas and in neighboring countries, as for example, in the French Guiana (Prost 1986).

The Committee on Geomorphology and Environmental Change of I.G.U., new publications on tropical geomorphology (Thomas 1994) and the International Association of Geomorphologists (I.A.G.) have encouraged studies on Brazilian geomorphology. Researchers stimulated by the group at Federal University of Rio de Janeiro assembled in regional meetings, such as the International Conference on Geomorphology in Rio de Janeiro, in 1999. One the most frequent themes in these encounters has been research on hillslopes, on current gullying and mass movements in the Brazilian southeast and other areas. The consolidation of the Brazilian Geomorphology Union confirms the wish of the geomorphologists to participate in the solution of the serious environmental problems of the country.

\section{References}

Abreu Castilhos J.A. \& Correa C.H.T. 1991. Avaliação preliminar dos processos erosivos na praia da Armaç̃o - Ilha de Santa Catarina, Florianópolis-SC. In: Simp. Geogr. Ffsica Aplicada, 4, Anais, 1:218-229

Ab'Sdber A.N. 1958. A Geomorfologia no Brasil. São Paulo-SP, USP, Noticia Geomorfologica, 2:1-8

Ab'Saber A.N. 1966. 0 dominio dos "mares de morms" no Brasil. São Paulo-SP, IGEOGUSP, 9 p. (Geomorfologia 2)

Ab'Saber A.N. 1969. Urn concetto de geomorfologia a service das pesquisas sobre o Quaternário. São Paulo-SP, IGEOG-USP,), 23p. (Geomorfologia, 18)

Ab'SSber A.N. 1970. Provincias geológicas e dominios morfoclimáticos no Brasil. São Paulo-SP, IGEOG-USP, 26p. (Geomorfologia 20)

Ab'SSber A.N. 1973. A organizacãa natural das paisagens inter e subtropicais brasileiras. São Paulo-SP, IGEOG-USP, 14 p. (Geomorfologia 41)

Ab'Saber A.N. 1982. Degradacão da natureza por processes antropicos, na visão dos geografos. São Jose do Rio Preto-SP, IBILCE-UNESP, 27p. (Inter-Facies 106)

Ab'S\&ber A.N. 1985. A gestão do espaço natural (relembrando Caraguatatuba 1967, para compreender Cubatão, 1985). Rev. Arquitetura e Urbanismo, 1:90-93

Angulo R.J.1989. Variacões na configuração da linha de costa do Paraná nas ultimas quatro décadas. In: ABEQUA, Congr., 2, Rip de Janeiro-RJ, Public Especial, 1, p.24

Baccaro C.A.D. 1983. Os processos de movimentos de massa e a evoluão das vertentes na serra do Mar. Dep. de Geografia - FFLCH - Universidade de São Paulo, São Paulo-SP, Dissertação de Mestrado, 165p.

Baccaro C.A.D. 1990. Estudo dos processes geomorfologicos de escoamento pluvial em area de cerrado, Uberlândia-MG. Dep. de Geografia - FFLCH - Universidade de São Paulo, São Paulo-SP, Tese de Doutoramento, 164p.

Batres V.B.K. 1978 . A foz do rio Itanhaem e areas adjacentes, estudo de geomorfologia costeira. Dep. de Geografia - FFLCH - Universidade de São Paulo-SP, Dissertação de Mestrado.

Bernardi H., Cordazzo C.V., Costa C.S.B. 1987. Efeito de ressacas spbre Blutaparon portulacoides (St. Hill) Mears nas dunas costeiras do sul do Brasil. São Paulo-SP, Cienc. e Cultura, 39:345-547

Bertoni J. 1978. Nomograma para solução de perdas do solo do Estado de São Paulo. In: II Encontro Nacional de Pesquisa para Conservação do Solo, Passo Fundo-RS, Anais

Bigarella J.J. 1978. A Serra do Mar e a porção oriental do Estado do Paraná. Curitiba, Secretaria do Planejamento and ADEA, $249 \mathrm{p}$

Bigarella J.J., Silva J.X., Duarte G.M. 1970.0 desastre de Guaratuba-PR. Curitiba-PR, Rev. IBPT, 14

Bigarella J.J. \& Suguio K. 1979. Ambiente fluvial: ambientes de sedimentação, sua interpretação e importância. Curitiba, ADEA, $183 \mathrm{p}$

Bittencourt A.C.S.P., Farias F.F., Boas G.S.V. 1990. Influência da deriva litoranea no desenvolvimento do esporão de Caixa-Pregos, baía de Todos os Santos-BA. São Paulo-SP, Rev. Bras, de Geociências, 20:197-200

Canali N.E., Oka-Fiori C., Guedes J.A., Nunes F.G. 1999. The Antonina and Paranaguá way's region, Brazil: environmental zoning. In: Regional Conference Geomorphology, Rio de Janeiro-RJ, Abstracts, p. 24

Carvalho G.R.F. 1984. Contribuição ao estudo da dinamica atual geomorfologica do morro da Peninsula em Guarujá-SP. Dep. de Geografia - FFLCH -Universidade de São Paulo, São Paulo-SP, Dissertação de Mestrado, 147p.

Gassed V. 1984. Estudo dos efeitos morfodinamicos pluviais no planalto de Goiania-GO Dep. de Geografia - FFLCH - Universidade de São Paulo, São Paulo-SP, Tese de Doutoramento, $138 \mathrm{p}$.

Christofoletti A. 1971. A teoria dos sitemas. Bol. de Geografia Teoretica, 1:43-60

Coelho Neto A.L. 1979. O processo erosivo nas encostas do macico da Tijuca-RJ. Inst. de Geociências, Universidade Federal do Rio de Janeiro, Rio de Janeiro-RJ, Dissertação de Mestrado

Coelho Neto A.L. 1985. Surface hidrology and soil erosion in tropical montainous rainforest drainage basin Rio de Janeiro. Inst. de Geociências, Universidade Federal do Rio de Janeiro, Rio de Janeiro-RJ, Tese de Doutoramento

Colangelo A.C. 1990. Movimentos de massa e evoluído geomorfologica nas vertentes marginais do lago-barragem de Paraibuna-SP. Dep. de Geografia - FFLCH marginais do lago-barragem de Paraibuna-SP. Dep. de Geografia
Universidade de São Paulo, São Paulo-SP, Dissertação de Mestrado

Colangelo A.C. 1995. Teste de experimentação com "sheargraph"e obtenção de limiares nas vertentes marginais do lago-barragem de Paraibuna-SP. Dep. de Geografia -

FFLCH - Universidade de São Paulo, São Paulo-SP, Tese de Doutoramento

Cruz O. 1974. A serra do Mar e o litoral na area de Caraguatatuba-SP. Inst. de Geogra-

fia, Universidade de São Paulo, São Paulo-SP, 181 p. (Serie Teses e Monografias, 11)

Cruz 0.1975. Evolução de vertentes nas escarpas da serra do Mar em Caraguatatuba-SP In: Simpó sio Internacional sobre o Quaternário, Anais, Academia Brasileira de Ciências-suplemento 47:479-480

Cruz O. 1982. Estudos dos processes geomorfologicos do escoamento pluvial na area de Caraguatatuba-SP. Dep. de Geografia - FFLCH - Universidade de São Paulo, São Paulo-SP, Tese de Livre Docencia, 151p.

Cruz O. 1998. A Ilha de Santa Catarina e o Continente proximo. Um estudo de geomorfologia Costeira. Florianopolis-SC, Editora Universidade Federal de Santa Catarina, 279p.

Cruz 0. \& Modenesi M.C. 1978. Some observations on the evolution of a gully in sediments of the São Paulo Basin, São Paulo. In: International Congress INQUA, BirminghanUK, Abstracts, 99:77-85
Cruz O., Suguio K., Eichler B.B. 1980. Sedimentação acelerada de pontais e barras arenosos na enseada de Caraguatatuba-SP. Causas naturais e artificiais. São Paulo-SP, USP, Bol. Inst. Oceanográfico, 33(1):39-53

Cunha S.B. 1993. Impactos das obras de engenharia sobre o ambiente biofísico da bacia do rio São Joao (Rio de Janeiro-Brasil). Departamento de Geografia. Universidade classica de Lisboa, Lisboa, $415 \mathrm{p}$.

De Martonne E. 1940. Problemes morphologiques du Bresil tropical atlantique. Annales de Geographie, 49:1-27 et 105-129

De Ploey Y. 1988. Concerning factors of soil erosion, with special reference to tropical areas. In: Latin American Regional Conference, Rio de Janeiro-RJ, Abstracts: 317 322

De Ploey Y. \& Cruz 0.1979. Landslides in the serra do Mar, Brazil. Catena, 6:111 -122

De Ploey Y, Cruz O., Modenesi M.C. 1983. Resistence au cisaillement et conditions de glissements de terrain a Caraguatatuba et a Campos do Jordão-SP. In: Estudo e cartografia de formações superficiais e suas aplicações em regiões tropicais. Colóquio interdisciplinar franco-brasileiro, Dep. de Geografia, FFLCH, Universidade de São interdisciplinar franco-brasil
Paulo, São Paulo, 1:393-402

Diehel F.L. 1997. Aspectos geoevolutivos, morfodinamicos e ambientais do pontal da Daniela, Ilha de Santa Catarina. Dep. de Geociências - CFH - Universidade FedeDaniela, Ilha de Santa Catarina. Dep. de Geociências - CFH -
ral de Santa Catarina, Florianopolis-SC, Dissertacão de Mestrado

Domingues E,N. 1983. Estudo de processos geomorfologicos do escoamento fluvial e evolução de vertentes na serra de Cubatão-SP. Dep. de Geografia - FFLCH - Universidade de São Paulo, São Paulo-SP, Dissertação de Mestrado, 153p.

Duarte G.M. 1981. Estratigrafla e evolução do Quaternário no plano costeiro none da Una de Santa Catarina. Departamento de Geografia, Universidade Federal do Rio Grande do Sul, Porto Alegra, Dissertação de Mestrado

Duarte G.M. 1995. Depositos cenozoicos costeiros e a morfologia do extremo sul de Santa Catarina. Instituto de Geociências, Universidade de São Paulo, São Paulo, Tese de Doutoramento

Farias E.F., Bittencourt A.C.S.P., Zanini Jr. A., Dominguez J.M.L. 1985. Variaç̃es temporais e espaciais na dinâmica de sedimentação da praia de Armação, Salvador-BA. Rev. Bras, de Geociências, 15:48-54

Feitosa A.C. 1996. Dinamica dos processos geomorfologicos da area costeira a nordeste da ilha do Maranhão-MA. Inst. de Geociêicias - Universidade Estadual Paulista, Rio Claro-SP, Tese de Doutoramento, $249 \mathrm{p}$

Furian S.M. 1994. Morphogenese/pedogenese en milieu tropical humide de la serra do Mar, Bresil, contribution de I'alteration et de la pedogenese a une dynamique actuelle de glissement. Caen-France, SLSCH, Tese de Doutoramento, 178p.

Furian Dias S.M. 1988. Os processos geomorfologicos do escoamento pluvial na estacdo experimental de Cunha-SP - Um esboço metodologico. Dep. de Geografia FFLCH - Universidade de São Paulo, São Paulo-SP, Dissertação de Mestrado, 187p.

Furtado V. V. 1978. Contribuição ao estudo da sedimentação atual no Canal de São Sebastiao-SP. Inst. Oceanografico, Universidade de São Paulo, São Paulo-SP, Tese de Doutoramento

Gr6 J.C.R., Abreu Castilhos J., Horn P N.0.1994. Morphodynamic and sedimentological study of the "Mole beach" Santa Catarina island, Brazil. In: Internacional Sedimentological Congress, 14, Recife-PE, Abstracts

Guerra A.J.T. 1994. The effect of organic matter content on soil erosion in simulated rainfall experiments in W. Sussex, U.K. Soil Use and Management, Harpender.

Guidicini G. \& Iwasa O.Y. 1976. Ensaio de correlação entre pluviosidade e escorregamentos no meio tropical úmido. Inst. de Pesquisas Tecnologicas, São Paulo-SP, 48p., (Publicação 1080)

Hermann M.L.P. 1999. Estudo de geomorfologia costeira nos municipios de São Jose, Palhofa e Biguafu-SC. Universidade Federal de Santa Catarina, Florinanopolis-SC, Tese de Doutoramento

Horn Filho N.O., Abreu Castilhos J., Gr6 J.C.R., Diehl F.L. 1994. Estudo geológico correlative entre o Quaternário costeiro das ilhas de São Francisco do Sul e de Santa Catarina-SC. In: SBG, Congresso Brasileiro de Geologia, 38, Balneário CamboriuSC

Jordão S. 1991. A mineração nos municipios de Guarulhos e Mairipora-SP. Aspectos geomorfologicos aplicados a sua organização e desenvolvimento. Dep. de Geografia - FFLCH - Universidade de São Paulo, São Paulo-SP, Dissertação de Mestrado, $250 \mathrm{p}$.

Kohler V.B. 1996. De Pontal do Sul a praia de Leste-PR, um estudo de geomorfologia costeira. Dep. de Geografia - FFLCH - Universidade de São Paulo, São Paulo-SP, Tese de Doutoramento

Lombardi F.N. \& Bertoni J. 1975. Tolerancia de perda da terra para solos do Estado de São Paulo. Campinas-SP, Inst. Agronômico, 12 p. (Bol. Tecnico 28)

Lombardi F.N. et al. 1979. Simulador de chuva e sua utilizacdo em pesquisa de erosão do solo. Campinas-SP, p. 81-98, (Bol. Inst. Agronomico 31)

Mauro C.A.. 1990. Voçorocas: marcas das relecoes sociedade-natureza na bacia do Monjolinho, São Carlos-SP. Dep. de Geografia - FFLCH - Universidade de São Paulo, São Paulo-SP, Tese de Doutoramento, 222p.

Meis M.R.M. \& Silva J.X. 1968. Considera9oes geomorfologicas a propósito dos movimentos de massa ocorridos no Rio de Janeiro-RJ. Rev. Bras, de Geografia, 30(1):55-73

Modenesi M.C. 1969. Memoria explicativa da carta geomorfologica da ilha de Santo Amaro - SP. Primeiros estudos. São Paulo-SP, IGEOG-USP, $15 \mathrm{p}$ (Aerofotogeografia 2) 
Modenesi M.C., Tessler M.G., Cruz O., Coimbra A.M. 1983. Influence of marine and continental processes on the dynamics of a sand-ridge at the mouth of the Massaguaçu river, Caraguatatuba-SP. Preliminary conditions. São Paulo-SP, USP, Bol. Inst. Oceanográfico, 32(1):77-81

Mousinho M.R. \& Bigarella J.J. 1965. Movimentos de massa no transporte dos detritos da meteorização das rochas. Curitiba-PR, UFPR, Bol. Paranaense de Geografia 16 17:43-84

Muehe D. 1984. Evidências de recuo dos cordões litorâneos em direção ao continente no litoral do Rio de Janeiro. In: Simpósio sobre Restingas, Origem, Estrutura, Proceslitoral do Rio de Jáni-RJ, Anais

Muehe D., Correa H.T., Ignaras S. 1989. Avaliação dos riscos de erosão dos cordões litoraneos entre Niterói e Cabo Frio-RJ. In: Simpósio de Geografia Fisica Aplicada, Nova Friburgo-RJ, 1:368-383

Pacheco M.M.S. 1991. Evolução e dinâmica geomorfologica das vertentes na área da escarpa entre Taquara e São Francisco de Paula-RS. Dep. de Geografia - FFLCH - Universidade de São Paulo, São Paulo-SP, Tese de Doutoramento, 126p.

Pellerin J. \& Paulino L.A. 1996. Aspectos geomorfológicos da ilha de Santa Catarina. In: SBPC, Reuniao Especial, 3, Florianópolis, Anais,

Pianaro A. 1982. Estudo hidrodinâmico da bacia do rio Tagaçaba, Guaraquecaba-PR Dep. de Geografia - FFLCH - Universidade de São Paulo, São Paulo-SP, Dissertação de Mestrado, $126 \mathrm{p}$

Pompeia S.L., Pradella D.Z.A., Martins S.E., Santos R.S., Diniz K.M. 1989. A semeadura aérea na serra do Mar, Cubatao-SP. Rev. CETESB de Tecnologia, 3:13-19

Pon9ano W.L. 1985. Sedimentação atual aplicada a portos no Brasil. Inst. de Geociências, Universidade de São Paulo, São Paulo-SP, Tese de Doutoramento

Prost M.T. 1986. Aspects of the morphosedimentary evolution of French Guyane Coastline In: Quaternary of South America and Antarctic peninsula, São Paulo-SP, 4:191-218

Queiroz Neto J.P. \& Christofoletti A. 1963. Ação do escoamento superficial das águas pluviais na serra de Santana-SP. São Paulo-SP, AGB, Bol. Paulista de Geografia, 45:59-71

Rochefort M. 1958. Rapports entre la pluviosite et lecoulement daus le Bresil subtropical et le Bresil tropical atlantique. Paris, France.

Ruellan F. 1953. O Papel das enxurradas no modelado do relevo brasileiro. São Paulo-SP, AGB, Bol. de Geografia, 13 e 14
Souza C.R.G. 1997. As células de deriva litorânea e a erosão nas praias do Estado de São Paulo. Inst. de Geociências, Universidade de São Paulo, São Paulo-SP, Tese de Doutoramento

Sternberg H.O.R. 1949. Enchentes e movimentos coletivos no vale do Paraiba em dezembro de 1949. Rio de Janeiro-RJ, IBGE, Rev. Bras, de Geografia, 11:223-261

Suertegaray D.M.A. 1987. A trajetoria da natureza: um estudo geomorfologico sobre os areais de Quarai-RS. Dep. de Geografia - FFLCH - Universidade de São Paulo, São Paulo-SP, Tese de Doutoramento, 243p.

Tavares A.C. 1986. A erosão dos solos no contexto da análise ambiental: o exemplo do alto curso do rio São Jose dos Dourados-SP. Dep. de Geografia - FFLCH - Universi-

dade de São Paulo, São Paulo-SP, Tese de Doutoramento, 254p

Tessler M.G. \& Furtado VV. 1983 . Dinâmica de sedimentacão das feicões de assoreamento da região lagunar Cananéia/Iguape-SP. São Paulo-SP, USP, Bol. Inst. Oceanográfico, da r:117-124

Thomas M.F. 1994. Geomorphology in the tropics. A study of weathering and denudation in low latituds. J. Wiley \& Sons.

Tomazelli L.J. \& Villwock, J.A. 1989. Processes erosivos atuais na costa do Rio Grande do Sul, evidências de uma tendência contemporânea de elevação do nível relativo do mar. In: $2^{\circ}$ Congresso ABEQUA, Rio de Janeiro-RJ, Publ. Especial, 1,16p.

Tricart J. 1961. Les caracteristiques fondamentales du systeme morphogenetique des pays tropicaux humides. Paris, Information Geograph
J. 1977. Ecodinâmica, Rio de Janeiro-RJ, IBGE

Tricart J. \& Cailleux, A. 1965. Traitede geomorphologie. Le modeledes regions chaudes, forets et savanes. Paris, SEDES

Villwock J.A. 1987. Processos costeiros e a formação das praias arenosas e campos de dunas na costa Sul e Sudeste brasileira. In: Simpósio sobre ecosistemas Sul e Sudeste brasileiro, sintese dos conhecimentos, 1:380-398

Wischmeier W.H. 1959. A rainfall erosion index for a universal soil loss equation. In: Soil Science Society of America, Proceedings, 23(2):246-249.

Contribution IGC-030

Received January 29,2000

Accepted for publication April 28,2000 